\title{
CONSTITUTIONALITY OF STATUTORY RENEGOTIATION
}

\author{
Charles S. Collier*
}

The so-called "Renegotiation Act" was enacted in its original form as part of one of the National Defense Appropriation Acts, which was approved April 28, 1942. The provisions thereof were amended in certain respects by the Revenue Act of $1942,{ }^{2}$ approved October 2I, I942, and again in July, 1943. ${ }^{3}$ The "Renegotiation Act" as amended ${ }^{4}$ is applicable to all contracts for an amount in excess of

* A.B. Igrr, LL.B. I915, S.J.D. 1932, Harvard University. Member of the New York Bar and the District of Columbia Bar. Professor of Law, The George Washington University. Special Assistant to the Attorney-General, February I942 to November 1943. Author various articles in legal periodicals.

${ }_{5} 6$ Stat. 245, $4 \mathrm{I}$ U. S. C. A. note prec. \$I (Supp. 1942) (Sec. 403 of the Sixth Supplemental National Defense Appropriation Act, 1942).

${ }^{2}$ Pub. L. No. 753, 77th Cong., 2d Sess. (Oct. 2r, 1942) (Sec. 8or of the Revenue Act of r942).

${ }^{3}$ Pub. L. No. 108, 78th Cong., Ist Sess. (July $x$, r943) (Military Appropriation Act, r944); Pub. L. No. 149, 78th Cong., Ist Sess. (July I4, 1943).

"For the purposes of a discussion centering on constitutional issues, it seems desirable to quote verbatim, rather than to summarize, or re-state, the "key paragraphs" of the Act. Although in all probability the Act will be amended by adoption of the pending Revenue Bill of 1943 , the basic features of renegotiation giving rise to much of the discussion that follows will remain. The most essential provisions (although there are other provisions of importance) are found in the following passages:

"Wherever in the opinion of the Secretary of a Department, the profits realized or likely to be realized from any contract with such Department, or from any sub-contract thereunder whether or not made by the contractor, may be excessive, the Secretary is authorized and directed to require the contractor or sub-contractor to renegotiate the contract price.

"Upon renegotiation the Secretary is authorized and directed to eliminate any excessive profits under such contract or sub-contract (i) by reductions in the contract price of the contract or subcontract or by other revision in its terms; or (ii) by withholding from amounts otherwise due to the contractor or sub-contractor any amount of such excessive profits or (iii) by directing a contractor to withhold for the account of the United States from amounts otherwise due to the sub-contractor, any amount of such excessive profits under the sub-contract, or (iv) by recovery from the contractor or sub-contractor through repayment credit or suit of any amount of such excessive profits actually paid to him or (v) by any combination of these methods as the Secretary deems desirable.

"Upon renegotiation pursuant to this section, the Secretary may make such final or other agreement with a contractor or sub-contractor for the elimination of excessive profits and for the discharge of any liability for excessive profits under this section as the Secretary deems desirable. * * Any such agreement shall be final and conclusive according to its terms and except upon a showing of fraud or malfeasance or a wilful misrepresentation of a material fact such agreement shall not be reopened as to the matters agreed upon, and shall not be modified by any officer, employee or agent of the United States.

"This sub-section shall be applicable to all contracts hereafter made, and to all contracts and sub-contracts heretofore made whether or not such contracts or sub-contracts contain a renegotiation or recapture clause unless (i) final payment pursuant to such contract or sub-contract was made prior to April 28, 1942 or (ii) the contract or sub-contract provides otherwise pursuant to sub-section (b), or is exempted under sub-section $i$ of this section 403 , or (iii) the aggregate sales by the contractor 
$\$ 100,000$ made by the War Department, the Navy Department, the Maritime Commission and R.F.C. subsidiaries and to certain classes of contracts made by the Treasury Department. The Act is to remain in force during the continuance of the present war and for three years after its termination. A bill in amendment of the existing law was recently introduced in the House of Representatives by the Chairman of the Ways and Means Committee. ${ }^{5}$

In discussing the constitutionality of Acts of Congress, it is necessary to give appropriate attention to three broad classes of constitutional questions: first, those relating to the basic legislative jurisdiction of Congress over the subject matter in question, the issues as to whether such subject-matter falls within the true scope of the enumerated powers of Congress; second, those relating to whether Congress has in the particular instance attempted to delegate its own "legislative" power to administrative officials or to the courts, or has prescribed a plan which if carried into effect would otherwise violate the constitutional principle of the separation of powers; third, those questions which relate to the character and extent of the impingement upon, and interference with, historically established and legally recognized private rights, privileges and immunities in the application of the Act.

In considering the constitutionality of the Renegotiation Act, the first group of questions relating to the basic legislative jurisdiction of Congress presents no serious difficulty. It seems too clear for argument that Congress has a general power to prescribe the forms and procedures to be followed in making contracts in the name of the United States, and to set up conditions precedent that must be complied with before agreements entered into by administrative officials can become legally binding upon the United States. The power to enter into contracts is indeed not mentioned specifically in the Constitution as a power granted to the Government of the United States. But obviously many of the express powers in the Federal Government, such as the power to borrow money, the power to raise and support armies, and the power to provide and maintain a navy could not be exercised effectively without an implied auxiliary power to enter into binding contracts.

"Powers thus exercised are what are called by Judge Story in his _Commentaries on the Constitution, resulting powers, arising from the aggregate powers of the government. He instances the right to sue and make contracts."

The basic power of the United States to enter into binding contracts would doubtless have been implied in any event, for, as the authors of the Federalist very

or sub-contractor and all persons under the control or controlling or under common control with the contractor or sub-contractor under contracts with the Departments and sub-contracts thereunder do not exceed or in the opinion of the Secretary concerned will not exceed $\$$ roo,000 for the fiscal year of such contractor or sub-contractor."

${ }^{5}$ H. R. 3687,78 th Cong., Ist Sess. (introduced Nov. 18, 1943). This bill proposing important additional amendments to the existing system was introduced in the House of Representatives by Mr. Doughton, the Chairman of the Committee on Ways and Means. "At this writing, it has passed the House and has undergone drastic, and questionable, amcndments at the hands of the Senate Finance Committee. Its effect on various phases of renegotiation is discussed in this symposium by Abels, infra p. 399. Its relevance to certain aspects of constitutionality will be referred to in this article.

${ }^{\circ}$ Strong, J., in Legal Tender Cases, 12 Wall. 457,535 (U. S. 1870). 
properly state with regard to resulting powers in general-" $\mathrm{Had}$ the Constitution been silent on this head, there can be no doubt that all the partciular powers requisite as a means of executing the general powers would have resulted to the government by unavoidable implication. No axiom is more clearly established in law or in reason than that wherever the end is required, the means are authorized; wherever a general power to do a thing is given, every particular power necessary for doing it is included."7

Reliance could properly be placed upon the "necessary and proper" clause of Article I, Section 8, par. (I8) of the Constitution, as giving to Congress the power to prescribe the legal requisites of contracts of the United States. ${ }^{8}$

In Ellis v. United States, the Supreme Court was called upon to deal with criminal convictions for violations of an Act of Congress which purported to limit the hours of labor of mechanics and laborers employed by the United States or any contractor or sub-contractor upon any of the public works of the United States to eight hours per day except in cases of extraordinary emergency. The constitutionality of the Act was upheld, and the conviction of Ellis, an independent contractor for "permitting" his workmen to labor during more than nine hours in a single day, on the construction of a pier at the Boston Navy Yard, was sustained. With reference to the basic power of Congress to insert a statutory term in contracts of the United States, the Court said:

". . . Congress, as incident to its power to authorize and enforce contracts for public works may require that they shall be carried out only in a way consistent with its views of public policy, and may punish a departure from that way. It is true that it has not the general power of legislation possessed by the legislatures of the States, and it may be true that the object of this law is of a kind not subject to its general control. But the power which it has over the mode in which contracts shall be performed cannot be limited by a speculation as to motives. If the motive be conceded, however, the fact that Congress has not general control over the conditions of labor does not make unconstitutional a law otherwise valid, because the purpose of the law is to secure to it certain advantages so far as the law goes. . . . The Government purely as a contractor, in the absence of special laws may stand like a private person, but by making a contract it does not give up the power to make a law, and it may make a law like the present for the reasons that we have stated."10

If we compare the Renegotiation Act with the Act whose constitutionality was assailed in the Ellis, case, it seems plain that the purposes of the Renegotiation Act are more obviously germane to the actual interests of the United States as a con-

${ }^{7}$ The Federalist, No. XIIV (Univ. Classics ed.) 3 ro.

8 "The Congress shall have power... (18) To make all Laws which shall be necessary and proper for carrying into Execution the foregoing Powers, and all other-Powers vested by this Constitution in the Government of the United States or in any Department or Officer thereof."

206 U. S. 246 (Ig07).

${ }^{10} \mathrm{Id}$. at 256 . To the same effect, see Hollis v. Kutz, 255 U. S. 452 (192I). 
tracting party than was the purpose of the statutory term limiting the hours of labor under review in the Ellis case. ${ }^{11}$

While both statutes involve an impingement upon the private interests and immunities of the independent contractor, the question of adjusting the final contract price concerns the United States in an immediate sense, and does not involve any intrusion into fields historically regarded as reserved to the States. But the hours of labor regulation discussed in the Ellis case suggests an ulterior purpose as well as an ulterior motive, and impinges upon the zone of State control over labor questions which was historically accepted prior to the enactment of the National Labor Relations Act of I935. From this point of view, the doctrine of the Ellis case rests upon principles that give greater latitude to the power of Congress to enact statutory terms for contracts of the United States, than would be strictly necessary in order to establish that the subject matter of the renegotiation law falls within the basic legislative jurisdiction of Congress.

It is not necessary in order to support the constitutionality of the renegotiation law to assume that Congress has an unlimited discretionary power to prescribe statutory terms of all sorts for all contracts of the United States. The renegotiation law is, in a generic sense at least, an appropriate means for reaching ends which Congress is constitutionally empowered to secure. This statute has a special and genuine relevance to the appropriate exercise of the war powers of the United States Government. In the first place the renegotiation law is designed to reduce the direct cost of the war to the United States by eliminating excessive profits to private individuals and firms arising out of contracts for war supplies and war services furnished to the United States. In the second place, the statute is designed to place a flexible but effective barrier to rising prices on war-time contracts. The legislation derived much of its support from the belief the proposed renegotiation system would operate as an important agency of price control and that forward prices would be held in check because of the knowledge on the part of all concerned that "excessive profits" would in any event be "recaptured."12 It must be admitted that the alleged beneficial effect of the renegotiation system on forward prices is widely questioned, and is indeed earnestly denied by many attorneys and accountants familiar with the actual working of the system. But from a constitutional standpoint the colorable purpose and the argumentative effect of the statutory plan in respect to the limitation of future prices support the conclusion that the objectives of the statute are legitimate and lie within the reach of the legislative power granted to Congress under our system of government.

In the third place, the renegotiation system is designed to stimulate greater efficiency in the operation of the various concerns which have war contracts with the

11 And cf. Atkin v. Kansas, I9I U. S. 207 (1903); People v. Orange County Road Const. Co., 175 N. Y. 84,67 N. E. 129 (1903); People v. Grout, I79 N. Y. 417,72 N. E. 464 (1904); People v. Metz, 193 N. Y. 148,85 N. E. 1870 (I908).

${ }_{12}$ Practices in Renegotiation of War Contracts (published by National Industrial Conference Board, Inc., 247 Park Ave., New York), p. I. 
United States, greater efficiency, that is, as technical production agencies, than would be the case were easy profits assured through lax supervision. In this aspect, the renegotiation system with its constant and anticipated inquisition into the necessity and legitimacy of all cost items and the reasonableness of profits secured by methods of increased efficiency, offers obvious advantages over the easy-going cost-plus-afixed-fee basis for determining war contract prices.

Finally, the renegotiation system is designed to strengthen national morale by giving assurance that no one will be allowed to make excessive profits out of war industry. This assurance is an important factor in securing the general willingness to make sacrifices of all sorts and to sustain the unavoidable costs of the war. The renegotiation system is designed to operate as a real factor in strengthening the moral unity of the nation and in inducing on all sides the willingness to make the maximum effort for victory.

It seems plain, then, that the ends for which the renegotiation system is designed are in themselves legitimate ends which are wholly within the war powers of the United States as contemplated by the Constitution.

As to the legitimacy of the particular means, namely, the renegotiation law, for reaching these acknowledged constitutional objectives, the frequently quoted words of Chief Justice Marshall in McCulloch v. Maryland ${ }^{13}$ seem peculiarly apposite:

"We admit as all must admit that the powers of the government are limited and that its limits are not to be transcended. But we think the sound construction of the Constitution must allow to the national legislature that discretion with respect to the means by which the powers it confers are to be carried into execution, which will enable that body to perform the high duties assigned to it, in the manner most beneficial to the people. Let the end be legitimate, let it be within the scope of the Constitution, and all means which are appropriate, which are plainly adapted to that end, which are not prohibited but consist with the letter and spirit of the Constitution, are constitutional." ${ }^{\text {14 }}$ (Italics added.)

\section{II}

If it be assumed that the subject matter of the Renegotiation Act is within the basic legislative jurisdiction of Congress, there remain many weighty objections to the constitutionality of the Renegotiation Act. Perhaps the most perplexing of these is the objection that the Renegotiation Act delegates unstandardized power to administrative officials and that this attempted action is unconstitutional because it amounts to an abdication by Congress of its primary responsibilities as a legislatve body and an attempted delegation of the entire legislative power of Congress in this field. Subordinate elements in this general objection are, first, that the act permits redelegation of full power in the premises to administrative subordinates, ${ }^{15}$ and second, that the administrative officials to whom in effect untrammelled power has been delegated are not obligated by the statute to act quasi-judicially or even to be

\footnotetext{
${ }^{10} 4$ Wheat. 316 (U. S., I8ig).

14 Id. at 421 .

${ }^{16}$ Pub. L. No. 753, 77th Cong., 2d Sess. (Oct. 2I, 1942) (Sec. 8or of the Revenue Act of 1942).
} 
impartial in an administrative sense, and that they are in fact "partisans" of the claims of the United States since there is no separation of the prosecuting and adjudicative functions in this field of governmental action. ${ }^{10}$

As regards this branch of the discussion it is important to distinguish at the outset between the prospective application and the retroactive application of the renegotiation law.

So far as concerns contracts within the scope of the renegotiation legislation that have been entered into since the operative date of that legislation, April 28, 1942, the statutory authority of the Secretaries to require the contractor or subcontractor to renegotiate the contract price so as to eliminate excessive profits must be read in as a statutory term constituting an integral part of each such contract. Each contractor and sub-contractor entering into such subsequent contracts must be deemed to have voluntarily assented to the renegotiation provisions. It becomes part of each such contract from the beginning that the final contract price is subject to reductions to be determined in amount by the application of the standard of eliminating excessive profits. This part or aspect of each such contract is as much entitled to legal recognition and enforcement as any other part. ${ }^{17}$

When Shakespeare put into the mouth of Marcus Brutus the words "This is my answer-not that I loved Caesar less but that I loved Rome more"-he set a pattern for many well-balanced legal opinions. The reason for upholding the contractual right of the United States to insist on renegotiation and the elimination of excessive profits as regards all contracts of the specified classes entered into after April 28, I942, is not that we respect the basic personal liberties and immunities of the independent contractor any the less, but that we respect the special contractual rights of the Government more.

In most instances, in contracts entered into after April 28, 1942, the provision for renegotiation and the elimination of excessive profits has been expressly stated as required by Sub-section (b) of the Act. There will thus be in almost all instances in contracts within the scope of the Act, an express written assent by the independent contractor to the investiture of power in the designated Secretary to require renegotiation, and to eliminate excessive profits. But even if such express contractual provisions were not included in the actual written text of the contracts, the same requirements would have to be read into them as necessary statutory terms.

There appears to be no fundamental reason why a formal contract between the United States and an independent contractor may not reserve to the United States unrestricted discretionary power to determine what rates, prices or charges shall be paid by the United States for property sold or services rendered to the United States by the other contracting party. This proposition, extreme as it may seem, is illustrated by the method of fixing telegraph rates on U. S. Government telegrams which has received continuous legislative and judicial recognition throughout the last 75 years.

${ }^{10}$ Ibid. Cf. Morgan v. U. S., 304 U. S. I (1937). ${ }^{17}$ Atkin v. Kansas, r91 U. S. 207 (1903). 
In the Post Roads Act of $1866^{18}$ the following provisions were included:

"And be it further enacted, That telegraphic communications between the several departments of the Government of the United States and their officers and agents shall in their transmission over the lines of any of said companies, have priority over all other business, and shall be sent at rates to be annually fixed by the Postmaster General. ..." (Sec. 2)

"And be it further enacted, That before any telegraph company shall exercise any of the powers or privileges conferred by this Act, such company shall file their written acceptance with the Postmaster General of the restrictions and obligations required by this Act. ..." (Sec. 4)

In these provisions relating to the rates to be charged for transmitting U. S. Government telegrams, no standard whatever is laid down as controlling the discretion of the Postmaster General in this field of action. There is no specification that the rates shall be compensatory, or even that they shall be such as to reimburse the telegraph companies for the direct or incremental costs incurred in rendering these services to the U. S. Government. Much less is there any implied requirement that the rates fixed shall be such as would be constitutionally requisite in the regulation of public utility rates, where no such contractual terms were involved. The telegraph rates on U. S. Government telegrams have always been fixed under the Act of I866 at levels below those required for commercial telegrams. For many years these rates were fixed at forty per cent of the rates on corresponding commercial services.

The explanation of this apparent anomaly in public utility law is that the telegraph companies are bound by their contracts given for legal consideration, to accept the discretionary ruling of the Postmaster General (and the Federal Communications Commission in succession to the Postmaster General) ${ }^{19}$ as the conclusive determination of the rates to be paid for the transmission of U. S. Government telegrams. The special contractual basis of the powers of the Postmaster General and the Federal Communications Commission has been regarded as sufficient to displace all the ordinary principles of public utility rate regulation that have been developed where no such contractual basis for the utility rates had been formed. This system for fixing telegraph rates has been referred to without disapproval in numerous judicial decisions ${ }^{20}$ and must be regarded as consistent with all basic constitutional requirements.

The contractual reservation of discretionary powers to officials of the U. S. Government in the renegotiation laws of 1942 seems genuinely analogous. But the powers reserved to the Secretaries under the renegotiation law, since they refer only to the elimination of "excessive profits" and control only particular contracts or

18 I5 STAT. 221 (1866).

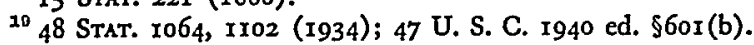

${ }^{20}$ United States v. Union Pacific Ry., 160 U. S. I (1895); Western Union Tel. Co. v. Penn. R. R., 195 U. S. 540 (1904); Pensacola Tel. Co. v. Western Union Tel. Co., 96 U. S. I (1877); Western Union Tel. Co. v. Ann Arbor R. R., I78 U. S. 239 (1900). 
groups of contracts that contemplate full performance within a limited time, are much less arbitrary and much less likely to disturb or undermine the permanent financial basis of the independent contractor's business, than the above-mentioned power of the Postmaster General in the field of the rates on U. S. Government telegrams.

It is important to emphasize the distinction between a standard established for the guidance of administrative officials, and a standard prescribed in a genuine police regulation, intended to be enforced in invitum upon all persons to whom it may apply. The standard prescribed for administrative action under the renegotiation law is admittedly a vague one whose meaning has not yet been determined with satisfactory precision. But as regards the prospective application of the law, that is, its application to the renegotiation of contracts entered into after April 28, I942, the standard prescribed, namely, the elimination of "excessive profits," is primarily a standard for administrative guidance. It is applied to outside parties only when they have voluntarily contracted with the United States in terms that purport to bind them to accept final prices which have been renegotiated and reduced in accordance with the authoritative interpretation of this standard.

From this point of view it seems plain that decisions like that in the Colen Grocery case $e^{21}$ are not apposite in relation to the prospective application of the renegotiation law. In the Cohen Grocery case, the Supreme Court was required to pass upon the constitutionality of the Lever Act of 19r9 which made it unlawful "for any person wilfully to make any unjust or unreasonable rate or charge in handling or dealing in or with any necessaries."22 No administrative body had been given authority to fix prices or to specify by detailed prescriptions what rates or charges were unjust or unreasonable. The statute was held void for uncertainty.

The decision in the Cohen Grocery case may perhaps be analyzed as a judicial condemnation of an attempt on the part of Congress to delegate legislative power to the courts. It is important to notice, however, that the decision may equally well be rested upon the Fifth and Sixth Amendments, as guaranties of individual liberties against criminal prosecutions in cases where neither the indictment nor the statute are adequate to inform parties charged with criminal misconduct as to "the nature and cause of the accusation." ${ }^{23}$ Persons who have never by any special contract with the United States subjected themselves to the control of a system of administrative interpretations of a vague standard established by law cannot be prosecuted criminally on the basis of alleged violations of statutory terms which are in themselves, and prior to any authoritative interpretation, too indefinite to establish any ascertainable standard of criminal guilt.

It should be noted also that the standard condemned in the Cohen Grocery case was "an unjust or unreasonable rate or charge." ${ }^{24}$ The prohibition against "exces-

\footnotetext{
22 United States v. Cohen Grocery Co., 255 U. S. 81 (I921).

224 S Stat. 297 (rgrg).

${ }^{23}$ See United States v. Cohen Grocery Co., 255 U. S. 8 I, 88 (rg2r).

24 Text to note 22, supra.
} 
sive prices" appears only in the conspiracy clause of the Lever Act-"it is hereby made unlawful . . . to conspire . . . to exact any excessive prices for any necessaries." Both of these standards seem to require consideration of many more factors than are involved in the concept, "excessive profits." Prices charged by a particular dealer might be "excessive" either in relation to actual costs or merely in relation to general market valuations of the commodities. "Unjust or unreasonable" rates and charges might or might not involve "excessive profits." In addition, the whole difficulty of defining "excessive profits" is potentially involved in the maximum generality of these standards in the Lever Act; for excessive profits might well be a factor in determining by a retrospective judgment what prices have been "unjust or unreasonable." But the Lever Act fails to provide any indication of the relative weight of the factor of excessive profits in the final determination, nor does it set up any administrative process for working out the standard through the contrast and analysis of divergent administrative rulings. The individual had to choose his own course under the Lever Act without any administrative guidance, and subject to oppressive criminal responsibility if his initial guesswork as to the meaning of the "standard" differed from the ultimate, better-informed, retrospective determination of a criminal court. The decision in the Cohen Grocery case does not require the condemnation of the renegotiation act.

The question of the legal sufficiency of the standard for administrative action prescribed in the Renegotiation Act must ultimately be faced. This is especially apparent with regard to the retroactive application of the law, for in this field the independent contractors cannot be regarded as having bargained to accept the discretionary judgment of the Secretaries. If the profits of past contracts can be recaptured at all, it must be in accordance with some definite standard of action that is to be consistently and equitably applied. But the legal sufficiency of the statutory standard is also vitally important with regard to the prospective application of the statute.

What then is the standard for administrative action which the renegotiation act as amended, contemplates? Section (a) paragraph 4 of the renegotiation act presents the following highly unsatisfactory substitute for a definition:

"The term 'excessive profit' means any amount of a contract or sub-contract price which is found as a result of renegotiation to represent excessive profits."25

Logically, this is not a definition, since the subject and predicate are substantially the same. For practical purposes, however, this attempted definition has some value since it shows that excessive profits are not to be ascertained by any particular formula. The statute attaches the label "excessive profits" to the findings of an administrative process. What is to guide this administrative process? Surely not alone the words "excessive profits," but also the whole plan and purpose of the renegotiation law.

${ }^{25}$ Pub. L. No. 753, supra note 2. 
Legal standards are always hard to define. What are "reasonable rates" for a public utility concern? What are reasonable as distinguished from unreasonable combinations in restraint of trade? What is "due care under the circumstances," the lack of which is so frequently provocative of tort liability? What are "good motives" and "justifiable ends" in the law of criminal libel? No precise definitions of these standards can be quoted. Yet the terms are pregnant with meaning and have a practical value as intelligible criteria in current judicial and administrative work.

There is, however, one very significant difference between the recognized legal standards just referred to, and the standard of "excessive profits" and that is the historically developed content or connotation of meaning which at the present time is associated with such standards as "reasonable rates" for public utility concerns. ${ }^{20}$ With regard to the standard of "excessive profits" this connotation is lacking, for we are at an earlier stage of the typical historical development of the meaning of standards through the process of inclusion and exclusion and through the approach and contact of authoritative decisions of divergent tendencies.

The most important effort to establish by administrative interpretation a concrete meaning, reasonably capable of consistent practical applications, for the statutory conception of "excessive profits," is the "Joint Statement" relative to "purposes, principles, policies and interpretations" under the Act issued by the War, Navy and Treasury Departments and the Maritime Commission, under date of March 3r, I943. ${ }^{27}$

The "Joint Statement" declares that the price adjustment boards are guided by the following broad principles: "(a) That the stimulation of quantity production is of primary importance." "(b) That reasonable profits in every case should be determined with reference to the particular performance factors present without limitations or restriction by any fixed formula with respect to rate of profit or otherwise." "(c) That the profits of the contractor will be determined on his war business as a whole for a fiscal period, rather than on specific contracts separately. ..." "(d) That as volume increases, the margin of profit should decrease. ..." "(e) That in determining what margin of profit is fair, consideration should be given to the corresponding profits in pre-war base years of the particular contractor and for the industry, especially in cases where the war products are substantially like pre-war products...." "(f) That the reasonableness of profits should be determined before provision for federal income and excess profits taxes." " $(\mathrm{g})$ That a contractor's right to a reasonable profit and his need for working capital should be distinguished. A contractor should not be allowed to earn excessive profits merely because he lacks adequate working capital in relation to a greatly increased volume of business."28

\footnotetext{
${ }^{26}$ Trustees of Saratoga Springs v. Saratoga Gas, E. L. \& P. Co., I91 N. Y. 123, 83 N. E. 693; Schechter Corp. v. United States, 295 U. S. 495 (1935).

${ }^{27}$ Joint Statement by the War, Navy and Treasury Departments and the Maritime Commission (March 3I, 1943). 
The Joint Statement also declares: "In determining the margin of profit to which a contractor is entitled, consideration is given to the manner in which the contractor's operations compare with those of other contractors with respect to the applicable factors; among such factors taken into consideration when applicable are the following:

(a) Price reductions and comparative prices.

(b) Efficiency in reducing costs.

(c) Economy in the use of raw materials.

(d) Efficiency in the use of facilities and in the conservation of manpower.

(e) Character and extent of sub-contracting.

(f) Quality of production.

(g) Complexity of manufacturing technique.

(h) Rate of delivery and turnover.

(i) Inventive and developmental contribution with respect to important war products.

(j) Cooperation with the Government and with other contractors in developing and supplying technical assistance to alternative or competitive sources of supply and the effect thereof on the contractors future peace-time business." ${ }^{29}$ (Italics added.)

If this statement of controlling principles had been enacted by Congress as an integral part of the original renegotiation statute, we should probably be "safe" in concluding that Congress has discharged its basic legislative duty with respect to prescribing a standard for the guidance and direction of administrative boards empowered to recapture "excessive profits." 30 Congress, on this supposition, would have given us a piece of legislation sufficiently explicit, definite, and certain to satisfy constitutional requirements. The Revenue Bill of I943, therefore, which sets up standards analogous to those in the Joint Statement, would seem to settle this issue of constitutionality with respect to fiscal years ending after June 30 , I943, the effective date mentioned in the Bill..$^{30^{2}}$

Now, may the "Joint Statement" issued on March 3I, I943, by administrative officials charged with the duty of enforcing the less articulate renegotiation statute that Congress did actually enact, be accepted as the legal equivalent of express statutory terms? The question is peculiarly important with regard to the intermediate period between April 28, 1942, when the renegotiation statute first became operative, and March 3I, 1943, when the Joint Statement was promulgated, and became available as an authoritative guide to practice under the statute.

In favor of an affirmative answer, the following considerations may be assembled: first, we are not dealing with the enforced application of a police statute generally upon all the citizenry, as to which reasonable certainty, definiteness and

so Id. at 8 .

${ }^{30}$ Hampton Co. v. United States, 276 U. S. 394 (1928); United States v. Darby, 312 U. S. 100 (1940); Panama Refining Co. v. Ryan, 293 U. S. 388 (1934) and annotation thereon in 79 L. Ed. $474-582$. 
clarity in the terms of the statute itself are constitutionally requisite. We are dealing with a standard which, however, unsatisfactory intrinsically has been contractually accepted by individual citizens and corporations who have also agreed to the authoritative interpretation of the standard by officials of the United States Government. ${ }^{31}$

Second, we are dealing with a standard laid down primarily for administrative guidance, and intended to be given color and content by intelligent and systematic administrative action, before being finally applied to actual business situations. In this respect, the criteria of the statute might be compared to the "public interest" criteria which appear in many statutes now generally acquiesced in; for example the provisions in Sections $5(\mathrm{~b})$ and $5(\mathrm{e})$ of the Interstate Commerce Act dealing with consolidations and combinations of carriers. By the terms of the statute just referred to, the Interstate Commerce Commission is authorized to approve such combinations, when falling within certain broad classifications "if the Commission finds" "the proposed transaction . . . will be consistent with the public interest."

Third, it must be kept in mind that what the Constitution requires in such matters is merely that Congress should make the essential legislative choices, should lay down appropriate standards for administrative action and should indicate with clearness the objectives at which interpretation and enforcement should aim..$^{33}$ It is not constitutionally' requisite that Congress should lay down precise rules, although, of course, Congress may prescribe such rules in its own formal enactments, if it chooses to do so. But where subject matter renders the exact delineation of detailed rules impracticable or undesirable, Congress in many instances has in its own primary legislation, merely prescribed broad and flexible standards leaving the detailed rules to be worked out by administrative bodies. It is an intelligible standard and not a body of precise formated rules which is constitutionally requisite. In order to establish the constitutional validity of the renegotiation act, it is not necessary to show that the legislation of Congress embodies a definite rule or rules which cover the ground and operation of the statute in a complete and exhaustive manner. It is merely necessary that Congress should have established an intelligible and adequate standard to govern administrative action and guide private parties in the ascertainment and vindication of their legal rights in the premises.

It seems plain that the determination of what profits are excessive is the gist of the renegotiation law. Since Congress has failed (unless it adopts the pertinent provisions of the pending Revenue Act of 1943) to provide an explicit definition, the only alternative means of securing a reasonable precise standard was for the renegotiation authorities either to promulgate formally a comprehensive interpre-

\footnotetext{
${ }^{31}$ Cf. Western Union Tel. Co. v. Penn. R. R., supra note 20; United States v. Cohen Grocery Co., supra note 2I; International Harvester Co. v. Kentucky, 234 U. S. 216 (19r4).

${ }^{32}$ N. Y. Central Securities Co. v. United States, 287 U. S. I2 (r932); Texas v. United States, 292 U. S. 522 (1934); United States v. Lowden, 308 U. S. 225 (1939).

${ }^{83}$ Buttfield v. Stranahan, I92 U. S. 470 (1904); Hampton Co. v. United States, stipra note 30; Panama Refining Co. v. Ryan, supra note 30; McKinley v. United States, 249 U. S. 397 (19r9); Schechter Corp. v. United States, supra note 26.
} 
tation, or to develop a thoroughly consistent practice through their successive adjudications. In either case, the standard thus arrived at could be supported as the "intended" legislative standard, on the ground that a highly generalized and vaguely expressed statement of the standard in the actual words of the statute had been given definite content and character by administrative interpretation. The Boards could treat the statutory language as if that language contained an explicit standard to govern their action.

But if, in spite of the formulation of the standard set forth in the Joint Statement, the renegotiation authorities in fact should exercise their discretionary power in such a manner that no consistent rules or principles can be extracted from the actual process, then we should after all reach the stage where we have a government of men, and not of laws in this particular field of governmental action. ${ }^{34}$

If we compare the standard for administrative action proposed in the renegotiation law with the defective standards in various statutes which have in fact been condemned by the United States Supreme Court, it seems plain that the renegotiation standard, vague and unsatisfactory as it appears in the bald sentences of the statute, is more readily capable than were any of the condemned "standards" of being made certain and definite for practical purposes by a process of systematic interpretation and application. ${ }^{35} I d$ certum est quod certum reddi potest. This optimistic maxim could not be justifiably applied with regard to the defective standards contained in the National Industrial Recovery Act of 1933 , for example. ${ }^{36}$ The standard in the Renegotiation Act at least points the direction in which administrative interpretation should proceed. Furthermore the field of permissible interpretation is relatively narrow. It is confined to what might properly be designated a single subject. Under the National Industrial Recovery Act, the field of possible action included every aspect or element in an extremely wide range of subjects. ${ }^{37}$ But furthermore that Act did not supply the fundamental directional principle ${ }^{38}$ or principles in accordance with which the administrative development of the incredibly numerous details might possibly have been organized. . As compared with the National Industrial Recovery Act, the Renegotiation Act relates to a limited field and the administrative rulings concern themselves with a particular issue-the elimination of excessive profits. The renegotiation boards do not have a roving commission to make rules about all sorts of industrial practices, as did the Code Authorities under the National Industrial Recovery Act, but are required to give

\footnotetext{
8t "Though the law itself be fair on its face and impartial in appearance yet if it be applied and administered by public authority with an evil eye and an unequal hand so as practically to make unjust and illegal discriminations between persons in similar circumstances, material to their rights, the denial of equal justice is still within the prohibition of the Constitution." Yick Wo v. Hopkins, II 8 U. S. $356,373-4$ (1886).

${ }^{35}$ International Harvester Co. v. Kentucky, supra note $3 \mathrm{x}$; United States v. Cohen Grocery Co., supra note 2I; Panama Refining Company v. Ryan, supra note 30; Schechter Corp. v. United States, supra note 26 .

${ }^{30} 48$ STAT. 195 (1933).

${ }^{87}$ Schechter Corp. v. United States, sipra note 26.

${ }^{88}$ Cf. Panama Refining Co. v. Ryan, stipra note 33 .
} 
their attention, "legislative" though it may be, to the attainment of a single though vaguely defined objective, the elimination of excessive profits.

A good contemporary example of delegated power which is unstandardized to a questionable extent, from a constitutional standpoint, can be taken from the Second War Powers Act. ${ }^{39}$ The foundation of the numerous regulations as to priorities issued under the authority of the War Production Board, is deemed by most persons who have examined the matter to be laid in the following brief statutory passage:

"Deliveries under any contract or order specified in this subsection (a) may be assigned priorities over deliveries under any other contract or order, and the President may require acceptance of and performance under such contracts or orders in preference to other contracts or orders for the purpose of assuring such priority. Whenever the President finds that the fulfillment of requirements for the defense of the United States will result in a shortage in the supply of any material or of any facilities for defense or for the private account or for export, the President may allocate such material or facilities in such manner, upon such conditions and to such extent as he shall deem necessary or appropriate in the public interest and to promote the national defense." ${ }^{\prime 0}$ (Italics added.)

Based fundamentally on this broad legislative authorization, many administrative orders of great importance have been issued. For example the Director of Industry Operations of the War Production Board (pursuant to a redelegation of this authority) has issued General Imports Order M. $63{ }^{41}$ and other orders of like character, which prohibit the importation into the United States of long lists of specific commodities, for private account, except where specific exception is made by authority of this Director of Industry Operations.

As compared with the Second War Powers Act, the Renegotiation Act seems to offer an equally definite standard. The objective of the one act is to eliminate "shortages" of essential war materials and facilities. The objective of the other is to eliminate "excessive profits." In both cases, Congress has made plain the direction in which the administrative effort in the interpretation and application of the law must move. But the reliance in both cases has been upon statutory terms whose meaning turns upon words in common use, "shortage" and "excessive profits," presented in the statutes without definition or elaboration. Perhaps the term "shortage" seems to have a superior clarity, because it suggests a mathematical admeasurement of supplies to actual military needs. But the risks of shortage must be determined in advance of the actual military needs and the actual administrative practice is to plan the adjustment of supplies to needs with the easement of a very large "factor of safety." The standards available for computation in this field of "shortages" prospective and potential offer fully as wide a field for discretionary

\footnotetext{
${ }^{39} 56$ Sтат. 176, 50 U. S. C. A. App. \$\$63I ff. (Supp. 1942).

1056 STAT. I78, 50 U. S. C. A. App. $\$ 633$ (Supp. 1942).

427 FED. REG. 4198 (1943).
} 
choice, as do the competing standards that may be brought into play to determine the value of the terms "excessive profits" under the renegotiation law.

There remain, however, two differences between these two statutory problems. First, the term excessive profits is more readily capable of exact definition than is the term "prospective shortage." It was not truly necessary to delegate such unstandardized power to the renegotiation boards. In the field of priorities it was unavoidable that a practically untrammelled flexible discretion to estimate the risks of shortages should have been delegated by Congress to the administration. Second, the priorities system is so close to the primary war effort, that the nature of the war powers of Congress perhaps justified the delegation of unstandardized power in the field of determining what sorts of shortages immediate or remote, intense, or slight, would make appropriate the application of priorities orders. Perhaps this power inheres in the constitutional prerogatives of the Commanderin-Chief in time of war, irrespective of any express delegations by Congress. ${ }^{42}$ But in the case of profits on war-contracts, while the nature of the war powers of Congress justifies some basic regulation, there seems to be no "military necessity" for a special adjustment or relaxation in this field of regulation in respect to the precision of the standards which Congress, in order to discharge its constitutional duties, ought to prescribe.

While, however, the term "excessive profits" is capable of being defined with precision in an accounting sense, it is very doubtful whether such a definition would express the will of Congress. The changes in the renegotiation law recently agreed upon by the Ways and Means Committee of the House of Representatives ${ }^{43}$ show that this Committee intends that the renegotiators shall "consider" such imponderable factors as "the contractor's efficiency" and "the extent of the risks he assumes," and "the nature of his contribution to the war effort" as well as "the potential financial burden to reconvert to peace-time operations." It seems clear that some at least of these factors can never be estimated with the precision of accountancy methods. The intended basis for the estimation of "excessive profits" remains different in essence as well as in detail from the precise and mathematical basis prescribed in other sections of the Revenue Acts for estimating the amount of excess profits for the purposes of excess profits taxation. ${ }^{44}$

It may be added that administrative practice under the Renegotiation Act has not adopted the same exclusions and deductions allowed in the Internal Revenue Code, despite the provision in the Renegotiation Act for recognizing exclusions and deductions of that "character," ${ }^{35}$ so that even the benefit of that reference for supplying a standard is lacking.

\footnotetext{
${ }^{42}$ Cf. United States v. Curtiss-Wright Corp., 299 U. S. 304 (1936).

¿3 Sipra note 5 .

"Internal Revenue Code, Chapter 2, Subchapter E, Excess Profits Tax, Sec. 710-752.

¿5y amendment in Pub. L. No. 753, 77th Cong., 2d Sess. (Oct. 21, 1942).
} 


\section{III}

The third main branch of our discussion must concern itself with what are usually called "due process" questions. The chief of these questions is as to the general validity of the retroactive provisions of the renegotiation law.

Subsection (c) (6) of the Act provides:

"This subsection shall be applicable to all contracts and sub-contracts hereafter made, and to all contracts and sub-contracts heretofore made whether or not such contracts or sub-contracts contain a renegotiation or recapture clause."

Exceptions to the general sweep of this provision are made with relation to cases in which final payment has been made pursuant to the contract, prior to April 28, I942, and cases involving contracts which have been specifically exempted under the provisions of the Act.

Can the flexible renegotiation provisions under discussion be made applicable, consistently with constitutional safeguards, to contracts and sub-contracts entered into prior to the operative date of the Act, April 28, 1942, in the very numerous cases in which such contracts or sub-contracts contained no renegotiation or recapture clause?

It has frequently been pointed out that the familiar clause in Article I, Section Io, of the Constitution: "No State shall ... pass any ... Law impairing the Obligation of Contracts," does not in terms apply as a restriction upon the legislative power of the United States. From this, the inference has been drawn that the Congress of the United States is not restricted by any constitutional limitation with respect to the retroactive application to prior contracts of statutes otherwise within its power to enact. ${ }^{46}$ We need not pause, in questioning this inference, to explore the implied limitations on the powers of Congress which its questioning would present; rather, suffice it to say that much of the ground covered by the contractimpairment conception is covered, as interpretations have turned out, by the provision of the Fifth Amendment that "no person shall . . . be deprived of life, liberty or property without due process of law" and the kindred clause "nor shall private property be taken for public use without just compensation." Furthermore these clauses inhibit abrogation, ${ }^{47}$ or any arbitrary modification of the legal incidents, ${ }^{48}$ of contracts of the United States itself. The protection against federal legislation which would have the effect of divesting previously valid contractual rights, is certainly not limited to instances of purely private contracts, or to contracts to which the United States is not a party.

In Perry v. United States, ${ }^{49}$ the Supreme Court was required to determine the permanent obligatory force of specific contractual agreements of the United Statesnamely, the agreement in bonds of the United States to pay principal and interest

\footnotetext{
${ }^{18}$ Legal Tender Cases, 12 Wall. 457 (U. S. I870); Julliard v. Greenman, I1o U. S. 42I (1884); Block v. Hirsch, 256 U. S. 135 (I921).

47 ynch v. United States, 292 U. S. 571 (1934).

${ }^{18}$ Perry v. United States, 294 U. S. 330 (1935).

${ }^{10}$ Tbid.
} 
of the bonds in gold coin of the standard of "value" legally established when the bonds were issued-as against subsequent legislation of Congress which provided that every obligation, whether or not containing such a "gold clause" should "be discharged upon payment, dollar for dollar, in any coin or currency which at the time of payment is legal tender for public and private debts."

Chief Justice Hughes in analyzing the special nature of public obligations of the United States in the course of the majority opinion in this case, said:

"In authorizing Congress to borrow money, the Constitution empowers Congress to fix the amount to be borrowed and the terms of payment. By virtue of the power to borrow money" on the credit of the United States, "the Congress is authorized to pledge that credit as an assurance of payment as stipulated, as the highest assurance the Government can give, its plighted faith. To say that the Congress may withdraw or ignore that pledge is to assume that the Constitution contemplates a vain promise, a pledge having no other sanction than the pleasure and convenience of the pledgor. This Court has given no sanction to such a conception of the obligations of our Government.".51

And as if to illustrate that this principle was not confined to the formal contract in public bonds of the United States payable in money, the Chief Justice quoted the following broad language from the Sinking Fund Cases, a controversy turning on the question whether certain action was warranted by a reservation to the Congress of the right to amend the charter of a railroad company.

"The United States are as much bound by their contracts as are individuals. If they repudiate their obligations, it is as much repudiation with all the wrong and reproach that term implies, as it would be if the repudiator had been a State or a municipality or a citizen." ${ }^{2}$ -

While the due process and just compensation clauses of the Fifth Amendment are by no means identical in purpose and scope with the clause in Article I, Section Io, forbidding State laws impairing the obligation of contracts, yet they may well establish constitutional limitations that will produce similar practical effects in many legal situations.

In discussing the concurrent operation of the diverse powers of the state and national governments upon the same subject matter, Chief Justice Marshall made the following illuminating statement in the course of his much rehearsed opinion in Gibbons v. Ogden:

"All experience shows that the same measures, or measures scarcely distinguishable from each other may flow from distinct powers; but this does not prove that the powers themselves are identical. Although the means used in their execution may sometimes approach each other so nearly as to be confounded, there are other situations in which they are sufficiently distinct to establish their individuality." ${ }^{33}$

\footnotetext{
${ }^{50} 48$ STAT. II2 (I933), 3 I U. S. C. 1940 ed. $\$ 463$.

01 Perry v. United States, 294 U. S. 330,35 I (I935).

${ }^{2}$ Ibid.

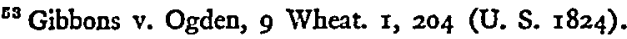


A similar statement might be made with equal propriety as to the partially coinciding or analogous operation of different constitutional limitations. The restraining effect of the impairment of contract clause upon the States may be "scarcely distinguishable" from the restraining effect of the due process clause of the Fifth Amendment upon the national government in some situations. This does not prove that the limitations themselves are identical. There are other legal situations "in which they are sufficiently distinct to establish their individuality."

Where the United States seeks through legislative action to abrogate contracts, and to divest the property rights which independent contractors have in contracts with the United States which were admittedly initially valid and obligatory, this action may well be regarded as legally "voided" by the restrictive force of the due process and just compensation clauses of the Fifth Amendment.

In Lynch $v$. United States, ${ }^{54}$ a decision in which a statute of Congress repealing "all laws granting or pertaining to yearly renewable terms insurance" was held unconstitutional, this argument was stated with classical simplicity and directness in the unanimous opinion of the Supreme Court delivered by Mr. Justice Brandeis.

"The Fifth Amendment commands that property be not taken without making just compensation. Valid contracts are property whether the obligor be a private individual, a municipality, a State or the United States. Rights against the United States arising out of a contract with it are protected by the Fifth Amendment. . . . When the United States enters into contract relations, its rights and duties therein are governed generally by the law applicable to contracts between private indivduals. That the contracts of war risk insurance were valid when made is not questioned. As Congress had the power to authorize the Bureau of War Risk Insurance to issue them, the due process clause prohibits the United States from annulling them, unless indeed the action taken falls within the federal police power or some other paramount power." 5

In the Lynch case, while giving contracts between the United States and private parties an impregnable position in most legal situations, the Supreme Court nevertheless left open a large "loop-hole" for possible legislative attack by the qualifying statement "unless indeed the action taken falls within the federal police power or some other paramount power." For the purposes of that particular case the "loophole" was not made use of. The court states:

"The Solicitor General does not suggest either in brief or argument that there were supervening conditions which authorized Congress to abrogate these contracts in the exercise of the police or any other power."

But in considering the retroactive application of the renegotiation law, this aspect of the authoritative and otherwise staunchly conservative opinion in the Lynch case seems to open up a vista of controversy.

The conception that the obligation and effect of contracts may be altered by action taken under the police power is derived from decisions in cases of several

Es Stipra note 47.

${ }^{5}$ Id. at 579. 
different groups. First, there are the cases where performance of a contract between private parties that was initially valid under the law of the State having appropriate jurisdiction has been rendered impossible by an exercise of federal power directed toward some recognized federal objective. The contractual obligation is displaced as an incidental result of the exercise of a federal power legitimate in itself. In this classification we may place the first of the Gold Clause Cases ${ }^{56}$ and cases like the Louisville Railroad case. ${ }^{57}$ Second, there are the cases dealing with the revocation of corporate charters, which authorize activities such as the operation of a lottery, or the maintenance of what would amount to a nuisance at common law. These charters are held to be "congenitally defective" as contracts. The states' police power cannot be bargained away. Although such charters have a tentative initial validity, they are not contracts protected by the clause forbidding legislative impairment in Article I, Section ro of the Constitution. Decisions which illustrate this classification are those in Stone v. Mississippi ${ }^{58}$ and Beer Company v. Massachusetts. ${ }^{69}$ Third, there are cases in which certain classes of agreements which are regarded as contracts in many legal situations are held to be outside the protection of the impairment clause; for example, marriage contracts, Maynard $v$. $\mathrm{Hill}^{, 0}$ and executory agreements for the payment of salaries or commissions to state employees, Butler v. Pennsylvania. ${ }^{61}$ Fourth, there are cases where legal incidents attaching originally to private contracts are held subject to abrogation, because they conflict with some legitimate state policy embodied in appropriate legislation which, however, leaves unchanged the most substantial elements of the rights secured under the contract by virtue of the law originally applicable. Examples of this classification would be state laws abolishing imprisonment for debt, ${ }^{62}$ state laws altering some of the incidents of the ownership of real property, ${ }^{63}$ and laws altering the rules of legal procedure in relation to the enforcement of contracts which leave available a substantial practical remedy for the protection of all existing contract rights. ${ }^{64}$

It seems entirely plain that the renegotiable contracts entered into by the various governmental agencies prior to the effective date of the Renegotiation Act does not fall within any of the categories just distinguished.

Since these contracts are entered into by the accredited agencies of the United States, on behalf of the United States itself in a substantial sense as the real party in interest in every case, there is no room for the application of the remote analogy of cases where legislation supervening upon private contracts formed under existing law has been held to have the effect of displacing or modifying the initial private rights and obligations arising out of such contracts. The war contracts to

${ }^{50}$ Norman v. B. \& O. R. R., 294 U. S. 240 (1935).

${ }^{67}$ Louisville \& Nashville R. R. v. Mottley, 219 U. S. 467 (IgrI).

${ }^{\mathrm{B}}$ ror U. S. 814 (I880).

${ }^{\circ 0}$ 125 U. S. I90 (1888).

ex Penniman's Case, ro3 U. S. 7I4 (1880).

${ }^{59} 97$ U. S. $25(1878)$

${ }^{81}$ Io How. 402 (U. S. I 850 ).

${ }^{83}$ Eldridge v. Trezevant, I60 U. S. 452 (I895).

oc Terry v. Anderson, 95 U. S. 628 (I877); Morley v. Lake Shore Ry. Co., I46 U. S. I62 (I892); Home Bldg. \& L. Assn. v. Blaisdell, 290 U. S. 398 (r934). 
which the renegotiation statute is addressed would seem to fall within the category illustrated by Perry $v$. United States, ${ }^{65}$ rather than within the category illustrated by the first Gold Clause cases. ${ }^{86}$ These contracts do not involve any attempt to "bargain away essential powers of the Government," but are separable specific contracts whose obligations leave the general regulatory powers of the United States wholly intact. Such contracts therefore bear no resemblance to the "perishable" charter contracts under consideration in cases like Stone v. Mississippi. ${ }^{67}$

It is certainly doubtful that a statute providing for the recovery of profits earned by the independent contractors can be regarded as the sort of modification by retroactive legislation which leaves unchanged the most substantial rights under the contracts, while only minor incidents are altered. Obviously this statute is not a mere modification of legal procedure. It is not fundamentally a moratorium statute with appropriate safeguards for both debtor and creditor, and does not therefore fall within the authority of decisions like the Minnesota Moratorium case. ${ }^{08}$ Furthermore the underlying policy of the renegotiation law is directed in its primary aspect to altering the obligation and effect of the contracts as an end in itself. It aims at "levelling the inequalities of fortune." The renegotiation law cannot be regarded as a statute directed primarily to the accomplishment of ulterior objectives, which incidentally and perhaps unavoidably displaces technical contract rights. The law upheld in the Minnesota Moratorium case had as its genuine primary objective the preservation of the class of independent farmers and home owners whose existence was theatened by the burden of their debts in a period of acute financial crisis and whose transformation into tenant farmers or itinerant laborers, uprooted from their own freeholds, would have involved sociological and moral consequences of the most serious sort.

On the other hand, may it not be said that the consequences sought to be avoided by the Renegotiation Act are fully as serious? After making due allowances for the benefits of "incentive," are not excessive profits derived from supplying the means to combat the common enemy, at a time of national danger and general sacrifice, as abhorrent as the prospects of an economically submerged class? True, it might be argued that in the renegotiation law the primary objective is a levelling of advantages derived from contracts established by free bargaining and that the attack on large profits derived from such contracts is an attack on the free enterprise system; also, that contracts made under a system of free enterprise between parties among whom the Government departments are certainly not the least powerful and made for business purposes with profits contemplated by all concerned as likely to accrue to the independent contractors, can hardly be analyzed as having "congenital defects" which from their first formation expose them to retroactive legislative attack and deprive them of the protection of paramount constitutional safeguards. Again, it might be argued that the constitutional safeguards in ques-

\footnotetext{
${ }^{\text {BE Supra note } 48 .}$

${ }^{88}$ Supra note 56.

${ }^{68}$ Home Bldg. \& Loan Assn. v. Blaisdell, supra note 64 .

${ }^{69}$ Coppage v. Kansas, 236 U. S. I, 18 (1915).
}

${ }^{\circ 7}$ Supra note 58. 
tion were intended to protect the system of free enterprise and to preserve to contracting parties and property holders the fruits or advantages which they had gained by their business activity and their bargaining capacity; and if such contracts as these war contracts are vitiated by "congenital defects" in a constitutional sense, then the exceptional case has become the controlling rule, and all or nearly all business contracts will be found subject to retroactive legislative displacement. But these arguments should be evaluated against the hard facts, in the background leading to renegotiation, that the sinews of war were urgently needed, that the "free" market of classical economics was absent, that the types of materials used were often new and their costs unknown. Finally, even if no "new" articles were involved, cannot the legislative power come to the relief of the buyer in a seller's market, even if the government itself is the buyer?

War contracts of the type covered by the renegotiation law have, of course, in certain circumstances been regarded as falling outside the range of the "congenital defect" doctrine, as is well illustrated by the decision and the reasoning of the Supreme Court in the recent Bethlehem Steel case. ${ }^{70}$ This case was a suit in equity. brought by the United States against Bethlehem Steel Corporation and its industrial subsidiaries for an accounting and for the recovery of sums paids under contracts for the construction of ships built for the United States under various wartime contracts entered into in I9I7 and I9I8. The Government argued that these contracts were invalid because unconscionable, specifying that the contracts were obtained under practical duress and that the profits were so grossly in excess of a standard established by common practice as to be accessible to recovery on equitable principles. Recovery was denied in the District Court, and this ruling was affirmed by the United States Supreme Court. In commenting upon the controlling issues, the Supreme Court said:

"The profits claimed here arises under contracts deliberately let by the Fleet Corporation under authority delegated by the President in accordance with an Act of Congress. Neither Congress nor the President restricted the freedom of the Fleet Corporation to grant measures of profit common at the time. And the Fleet Corporation's chosen policy was to operate in a field where profits for services are demanded and expected. The futility of subjecting this choice of policy to judicial review is demonstrated by this case. . . Under our form of government we do not have the power to nullify it as we believe we should necessarily be doing were we to declare these contracts unenforceable on the ground that profits granted under Congressional authority were too high."71 (Italics added.)

Are the profits accruing under war contracts made prior to April 28, I942, "granted under Congressional authority" in the same sense as the profits obtained by the Bethlehem Steel Corporation and its subsidiaries in the period of the first World War? Did the rights of independent contractors which accrued prior to the actual enactment of the renegotiation law become legally "vested" in accordance with the

${ }^{70} 315$ U. S. 288 (1942).

${ }^{71}$ Id. at 308 . 
doctrine announced in that case? (The case, be it noted, was rendered on February x6, 1942, with full cognizance of its implications under contemporary wartime conditions.) Or is there a distinction between a court's refusal to lay down, without statutory sanction, a common law (or equity) contract doctrine of economic duress and the constitutional validity of a statute?

The probability is that the Supreme Court will in the end give sympathetic recognition to the considerations that militate in favor of the constitutionality of the present renegotiation statute even in its retroactive application. In the first place, some of the war contracts made prior to April 28, 1942, may be found to be positively unconscionable within the sphere allowed for that concept, even under the liberal views expressed by the majority of the Supreme Court in the Bethlehem Steel case. ${ }^{72}$ In the second place, while the contracts made prior to the statute are formally complete, it seems possible, in view of the extreme urgency of the Government's military needs and the novelty of the industrial and accounting problems that had to be faced, to develop a doctrine that these contracts did not create rights of property that should be regarded as legally "vested" in all respects. From a factual standpoint these wartime contracts have had an experimental character in many instances. It would not be altogether surprising if, against a background of haste, lack of informative data, experimentation and tenuous moral claims to large profits at public expense in times of universal sacrifice, the Supreme Court should hold that contracts subject to renegotiation should be classified as possessing only a tentative or precarious validity in a legal sense, that is, as not creating legal rights so fully vested as to be protected by constitutional guarantees against any sort of reasonable and equitable "corrective" legislation. As Mr. Justice Daniel said in Butler v. Pennsylvania ${ }^{73}$ with reference to the scope of the clause forbidding state laws impairing the obligation of contracts: "The contracts designed to be protected are contracts by which perfect rights, certain definite fixed private rights of property are vested. These are clearly distinguishable from measures or engagements adopted or undertaken by the body politic or state government for the benefit of all, and from the necessity of the case...."74 (Italics added.)

In spite of the lack of any specific precedent, it seems possible to recognize in these wartime agreements for the furnishing of war necessities, a special classification of contracts that because of the circumstances of their origin are subject to the potentiality of subsequent legislative adjustment. The "congenital defect" theory could, both in a logical and in a practical sense, be extended to cover this additional and limited class of contracts, without endangering the security of "perfect rights,"

\footnotetext{
72 'For, high as Bethlehem's $22 \%$ profit seems to us, we are compelled to admit that so far as the record or any other source of which we can take notice discloses, it is not grossly in excess of the standard established by common practice in the field. . . . The Government made no attempt to cstablish, nor is there any indication in the record that the profits realized by other shipbuilders were any less than Bethlehem's." U. S. v. Bethlehem Steel, 3 I5 U. S. 288, 305, 306. The dissenting opinion of Mr. Justice Frankfurter has special significance with regard to the probable judicial attitude in more extreme cases of "unconscionable" war profits. 315 U. S. 288, 3 r2.

supra note $6 \mathbf{r}$.

74 Id. at 416 .
} 
fully vested rights of property, except in the same sense that these vested rights are already endangered by the admitted recognition of the "congenital defect" theory in other appropriate situations.

And in the third place, the admitted constitutionality of retroactive income and excess profits taxation extending back over comparable periods of time, indicates that excessive profits, unlike most other terms and incidents of contracts, are not in their essential nature beyond the reach of federal legislation. While the formal differences between renegotiation procedure and excess profits taxation are obvious, the practical differences in the ultimate results are relatively small, especially if we consider the more searching forms which excess profits taxation might take, without violating constitutional limitations. Special income taxes applicable exclusively to income from certain designated sources have already been resorted to, as in the instance of the special tax on the profits of sales of silver. ${ }^{75}$ The only kind of uniformity that is constitutionally requisite with regard to income and excess profits taxation is geographical uniformity. ${ }^{76}$ There is no fundamental reason why a special income tax could not be laid on the excessive profits gained from contracts for necessary war supplies.

The most hopeful basis for attacks on the rulings under the renegotiation law would therefore seem to be, not the basic constitutionality of the statute, but the maladministration thereof in specific cases, if such can be demonstrated. In this field as in other fields the rights secured to the individual under procedural due process must be observed. Arbitrary discrimination, radical unfairness in procedural methods, or intentional disregard of the practical standards which the statute must be regarded as laying down, cannot be reconciled with constitutional safeguards. Such abuses will doubtless be recognized in appropriate instances as grounds for judicial relief, but such cases should be dealt with on an individual basis, and ought not to be disposed of through a blanket condemnation of the entire statutory plan.

${ }^{75} 48$ STAT. 1178 (1934).

${ }^{70}$ United States v. Hudson, 299 U. S. 498. The Silver Purchase Act of June 19, 1934, imposed on all transfers of any interest in silver bullion, where the sale price exposed a profit over the original cost and allowed expenses, a tax of fifty percent of such profit. The tax was to be paid by affixing to a memorandum of the sale stamps to the amount of the tax. The tax was analyzed by the Supreme Court as a special income tax, and upheld as constitutional on this basis.

In delivering the unanimous opinion of the Supreme Court in this case, Mr. Justice Van Devanter said:

"The taxing provision does not impress a tax in respect of all transfers but only in respect of such as yield a profit over cost and allowed expenses. If there be no profit there is to be no tax. If there be a profit the tax is to be $50 \%$ of it. Because of this, counsel for the Government contend that the tax is a special income tax; and we think the contention is sound.

It is not material that such profit is taxed, along with other gains, under the general income tax law, for Congress has the power to impose an increased or additional tax, if satisfied there is need therefor." (Italics added.) 